\title{
UNDERSTANDING THE SPIRITUALITY OF TEACHER LEADERS IN EDUCATIONAL INSTITUTIONS IN ASIA
}

\author{
Fritzie Ian P. De Vera
}

De La Salle University, The Philippines

\begin{abstract}
This study aims to understand the spirituality of teacher leaders in selected educational institutions in Asia. It proposes to describe the impact on how spirituality affects the overall teaching performance and leadership of teachers in the schools. It will use a mixed method research design which will analyze quantitative and qualitative data looking into possible factors, such as religion, age and tenure, that might affect the level of Spirituality of teacher leaders and describing individual experiences in teaching and leading. A baseline quantitative data was gathered from a total of sixtyone (61) teacher leaders, identifying their level of spirituality and correlating this with religion, tenure in the educational institution and age. A spirituality assessment tool that measures the spirituality based on the core values of the school was used to assess the level of spirituality of teacher leaders. Initial findings through statistical analysis showed that religion is significantly correlated with spirituality. Non- Christian respondents were assessed to show lower levels of spirituality than respondents who are Christians. However, other factors like age and tenure showed no significant effects on spirituality. Still a work in progress, this study will further gather qualitative data through interviews of select respondents describing their experiences and stories on how spirituality affects the way they teach students and lead teacher subordinates. This study further aims to identify the characteristics of teacher leaders from varied faith backgrounds and how their spirituality affects their leadership in creating an effective teaching and learning environment in an educational institution.
\end{abstract}

Keywords: Spirituality, educators, religion, teacher leaders

\section{Introduction}

In all educational institutions teachers are very much expected to contribute in achieving a meaningful learning experience for the students. Teachers and curriculum leaders play a very major role in the development of the curriculum (Bago, 2008) of any institution. The goal to create an effective learning environment for students are expressed in the vision-mission and values of institutions Educational institutions have set mission, vision and values that are expressed and integrated in the curriculum. For many institutions teachers share in the role of leading in schools in ensuring that the goals of the schools are met. Teacher leaders share in the responsibility for the success of the school (Harrison \& Killion, 2008). They play various leadership roles like curriculum specialist, school leader, mentor, coach, facilitator etc. These roles may be assigned formally and informally by the school (Harrison \& Killion, 2008). Thus teachers who become leaders and are expected to understand, appreciate and imbibe the values and principles of the institution where they belong to effectively contribute in the development and implementation of the curriculum or the overall learning experience of any student. They should able to experience and identify the connection between the school's mission -vision with their own personal mission-vision and goals (de Kierk-Luttig, 2008). Especially for teachers who hold important and leadership roles in the school, they share in the implementation of the mission and vision of the institution. This way both teachers and students can achieve their potential and become "the best human beings they can be" (de Kierk-Luttig, 2008). However, this will not be achieved if teacher leaders will have different attitudes and values to that of the institution. Attitudes and values of teachers greatly affect the learning behavior of the students (J. A. Lindholm \& Astin, 2006). Issues and problems of teachers who serve as mentors may affect interaction with students, which was believed to be one of the most important learning opportunity for students 
(A.W. Chickering, 1969). Some if not most teachers just like professionals in the corporate setting may not see the connection and meaning of what they are doing in the institution to their own personal search for purpose. They may not see the ministry of teaching and leading a school as a vocation.

Connection of values of teacher leaders and the values of the institution can be achieved if the experience of teaching will serve as an opportunity for teachers to be holistically formed and developed. Formation of teachers as leaders should then be a major part of the goals of any educational institution. Educational leaders in any learning institution should make formation of their teachers as a priority.

Lasallian institutions are educational institutions ran by a congregation founded by St John Baptist De La Salle a French priest that lived in the 17th Century. They call the congregation the Brothers of the Christian Schools. Lasallian schools are Catholic schools which its primary aim is to "provide human and Christian education to the young especially the poor" (Guiding Principles of the Philippine Lasallian Family, 2009). These schools consider any one working "together and by association" towards the achievement of its mission as Lasallian (Circular 461, 2010). Further "Lasallian" is described as "a person who considers himself or herself as being in relationship of belonging with the Lasallian family or Lasallian institutions. This sense of belonging can be simply an affective one or it could also be simply an institutional one"(Botana, 2008). Lasallians, Botana (2018) mentioned then can be a "teacher... Christian, believer... in reference to John Baptist de La Salle, and therefore it designates the person who participates in the Lasallian mission based the Lasallian spirit". Teachers who hold leadership roles and have bigger responsibilities in Lasallian institutions are called Lasallians and are recognized to have a vital role in the formation of students and the sharing of the Lasallian mission and spirit.

With the existence of Lasallian institutions in Asia and around the world, Lasallian educators now come from varied cultural and religious backgrounds. This study is a description of how the Lasallian Spirituality is lived by these educators who hold an important role and responsibility in schools by being teacher leaders from different faith and religious backgrounds. The study will look into the factors on age, religion and tenure in a La Salle school that might affect their Lasallian Spirituality. It aims to provide an in depth description on how they become witnesses of the values and principles of the different La Salle schools in Asia and how they are effectively creating a positive impact in the learning experience of students entrusted to their care.

The study of Lasallian teacher leaders is a significant contribution in further understanding teacher leaders and administrators of the various Lasallian schools in the Asia and the Pacific. Given the diversity of cultures and backgrounds of these leaders, this study hopes to provide a common denominator of what makes these leaders uniquely Lasallian. The study will further contribute to the formation and development of teacher leaders. The deeper understanding of how spirituality has affected the way they teach, lead and influence students can also provide additional knowledge on how educational perspectives are shaped or created in schools (J. a. Lindholm, 2007). Moreover, the conversations that will be drawn from teacher leaders of different faiths and religions may provide an input on how interreligious or interfaith dialogues can be integrated in the teaching and learning process. As educators with different faith in a Catholic context, they can provide insights of how their spirituality is enriched with the Lasallian values of faith, service and communion in mission, which can be key to further formation of future Lasallian educators as leaders of institutions.

With this, educational leaders or administrators of the schools may be able to define the proper and needed approach to effectively form and develop these teacher leaders to become educational leaders who can effectively influence curriculum development including the overall teaching and learning experience on campus. This study may provide key decision points for educational leaders in managing teacher leaders from various backgrounds. Finally, decision-making considerations on hiring, developing and motivating teacher leaders may also be drawn from their insights and stories of how they continue to stay in the ministry of teaching, leading teachers and mentoring of students. 


\section{Religion and Spirituality}

There have been numerous studies on religion and spirituality and how the two are differentiated. Certain studies predict that both religion and spirituality affect a person's personality (Saroglou \& Muñoz-garcía, 2008). In the same manner, religious beliefs affect the way the person think, feel, and behave across a variety of context. In studies on religiousness vs spirituality, it provides evidences why people value spirituality more than religiousness, saying that there are some people who are more religious than spiritual (Zinnbauer, Pargament, and Scott 1999). In the study of Saroglou \& Muñoz-garcía (2008) differentiated modern spirituality which "(a) includes a reference to transcendence or the sacred but not necessarily God or gods as defined within religious traditions and (b) emphasizes an individual reality of connection with transcendence, others, and the world in general, without necessarily belonging or referring to a particular religious institution or group" (e.g., Hill et al. 2000; Miller and Thoresen 2003; Piedmont 1999 cited at (Saroglou \& Muñoz-garcía, 2008). Thus spirituality may or may not be affected by religious beliefs or associations. Spirituality, in the same study is explained to be an autonomous expression of the individual's relation to a transcendence or is independent to beliefs to a certain religious affiliation. Further both religion and spirituality play a very vital role in creating and understanding the meaning of one's life. In a review made by Farrell (2003) on the book of Robert Nash on Religious Pluralism, religion is mentioned "help us understand who we are, whom we belong to, how we should behave, and how we might come to grips with the mystery of our existence?" Spirituality and religion is further differentiated stating that religion is an organized community of faith while spirituality is more about personal belief and experience of a higher power (Tisdell, 2001). Further this study of Tisdell (2001) also presented a qualitative study identifying the three themes the further development of self-awareness, a sense of interconnectedness, and a relationship to a higher power. Thus with the definitions presented spirituality provides a common understanding the spirituality is important in the exercise of meaning-making in one's life. A study was done to identify the role of religion and spirituality in doing social work and the authors conclude that social work practitioners should consider the significance of religious and spiritual beliefs in their training and in the professional practice (Gilligan, P. and Furness, S., 2006).

In the various studies religiousness or religion and spirituality have varying effects on the personality, values and beliefs of a person. Thus both constructs can be used to understand people's approaches, principles and biases. These aspects in a person's life can actually be a means to achieve personal transformation and development.

\section{Spirituality in Academe}

Spirituality is believed to make a significant role in the life of a teacher. Various studies present the importance of spirituality in teacher formation and pedagogy in schools.

In the study on teachers in South Africa, there is a need to develop spirituality among the teachers. Teachers should be made to see the connection of the vision, mission and values of the school to the values and personal mission of teachers. With this teachers will consider the work of teaching as a vocation (de Kierk-Luttig, 2008). Concepts on spirituality should be used and introduced to teachers allowing them to go through the process of meaning making for them to better understand and appreciate the work as vocation that allows them to be more connected and whole. Further recommendations for teachers include:

"Mindfulness should be developed in teachers so that they can bring greater awareness to everything that happens at school, be more present in the moment and more aware of the dynamics of relationships. Teachers are engaged in the service of others and this dedication to the welfare of others creates a space for spirituality". (de Kierk-Luttig,2008) 
Further in the study conducted by Lindholm and Astin (2006) on understanding the interior life of faculty, they mentioned that when faculty tend to be disconnected or live fragmented lives, when spirituality becomes unimportant in the way the live their lives, they can be very unaware of their deeply felt values and would avoid discussions on meaning and purpose of what they do. This then will lead faculty to have competing values and thus will greatly affect how they engage with students. Faculty will then have to choose between prioritizing advancing knowledge on the field vs. the commitment to educate students and serving the community, choosing individual professional pursuits vs nurturing an intellectual community (J. A. Lindholm \& Astin, 2006). The study also further discussed that the behavior and attitude of faculty members greatly affect or are important to student development. The actions of the faculty in and outside the classroom can affect the learning environment of students and their career development. Faculty are primary adults in ensuring socialization that can impact student outcomes and experiences both positively and negatively (Chickering 1984 as cited in J.A Lindholm \& Astin, 2006). Interaction with faculty not just affect intellectual and professional development but also enhance personal identity awareness and moral development. Thus this particular study highlighted the importance of the spiritual development of teachers in any educational institution. Highly spiritual teachers enhance the students' personal development, civic- minded values, diversity advocacy, student-centered pedagogy, civic-minded practice, and positive outlook on work and life (J. a. Lindholm, 2007) Studies on the development of spirituality among faculty or teachers are quite a few compared to studies on the spirituality of students in schools. However it is equally important to look into the different impacts of spirituality on how this can positively change teachers in the way they teach and influence students (J. A. Lindholm \& Astin, 2006). In looking at the level of spirituality of teachers in higher education the results on this particular study showed that gender has an impact on the level of spirituality. Women are more spiritually inclined than men. Age was also a factor in determining the level and depth of spirituality among teachers. This is so because those who have gained experience and security in professional work tend to be more content with what they have and not seek for further selfactualization. Their lives are more integrated and balanced in the way they view their work and family life. Race and ethnicity were also factors that affected the level of spirituality of teachers as well as cultural backgrounds (J. A. Lindholm \& Astin, 2006).

Spirituality has become a major theme not just in professional work and in academe. It has become an important aspect of human experience and avenue for learning and meaning making. Thus it shouldn't be ignored especially in the aspect of teaching and meaning making. (Tisdell, 2001). Spirituality is so important that it also affect the way people lead. Spirituality has a big role to play as well in portraying leadership roles (Bolman and Deal, 1995).

\section{Spirituality in Leadership}

In the study on the role of spirituality in the work of African-American women spirituality was seen to influence decision making and their views on leadership. It also influenced their personal choices in their work as principal and the ways they made their spirituality visible in school (Atlas, 2002). Moreover, these principles conceptualized spirituality as acknowledging that there is a higher being outside themselves, their relationship with the Higher Being and being able to be guided by this in every aspect in their lives (Atlas, 2002). In a similar study conducted on African American men who were administrators and at the same time pastors, spirituality has an impact in portraying their leadership roles. The findings of the study suggested that administrators should consider nurturing spirituality among leaders in the schools that will help cultivate a nurturing, caring and supportive school environment. It further suggested that professional development programs and workshops should include leadership and spirituality modules. (Jones, 2010). Furthermore the participants of the study also considered spirituality as way for them to connect with teachers, students and the community through building good relationships (Jones, 2010). In both studies on African -American women and men leader's spirituality has an influence in their leadership and in their decision making. Both studies also 
suggested that spirituality helps in the nurturing of relationships with students and teachers. Thus spirituality becomes part of their core personal values influencing the way they relate and the way they lead schools. This is also supported by a study on school leadership and Spirituality conducted in Public and Catholic schools in Ontario. Spiritual practices of the school leaders were analyzed and how these affect their role as leaders. The study reported that their sense of spirituality is related to their core values. The participants considered spirituality as an integral part of who they are and this serves as a solid foundation of their work as school leaders (Dalia, 2005). This study further suggests that spirituality adds a dimension of the different theories of leadership. Spirituality serves as an orientation, a perspective and a motivator for school leaders (Dalia, 2005). Another study that provides a confirmation of spirituality having an impact on the decision making of leaders is a study done on public school teachers by Massenburg (2010). The study showed that spirituality of public school teachers and administrators evolved from their upbringing, specifically their religious background and influences from their parents. The study also emphasized that spirituality motivates them in making decisions that are critical in their work (Massenburg, 2010). The findings that support the interrelatedness of spirituality and religion also is shown in the study that reviews documents on definitions, distinctions of spirituality and leadership. In the study spirituality is tied to religion and leaders and managers can associate their drives and motivations on both spirituality and religion that affect their decision making process.

The impact of spirituality on leadership is supported by various studies that showed how leadership is influenced by spirituality in the areas on decision making and motivations. In this particular study Lasallian Spirituality is described and how this aspect of being Lasallian will have an effect on how teacher leaders lead and teach students in Lasallian educational institutions.

\section{Lasallian Spirituality}

Spirituality as we have defined it in several studies presents a way of living of an individual. This also describes how an individual relates to a higher being or God. Lasallian Spirituality as defined by Botana (2008) is a way of living Christian spirituality with the special perspective or dimension imparted by the Lasallian Charism. The Lasallian Charism and identity refers to the three "core values of Faith, Service, and Communion in relation to the training and formation of Lasallian associates and partners, the conduct of the Lasallian educational mission in schools and the socio-political involvement of the Lasallian Family" (Guiding Principles of the Philippine Lasallian Family, 2009, p. 5) Moreover he defines Lasallian Spirituality as a form of living the ecclesial communion for the mission. In addition Botana (2008) states:

Lasallian spirituality helps us to discover and to live our work of education as the privileged place of the educator in relation to God. Lasallian spir- ituality develops as a "spirituality of mediation", for it shows us how we ourselves are instruments in God's work, as mediators of his work of sal-vation with the young, ministers and representatives of Jesus Christ, the living word of God for those to whom we are sent. (p.65)

He made mention as well that the core of Lasallian spirituality is the spirit of faith and zeal where God is revealed or discovered through the mission that one has committed himself into (Botana 2008). These two areas "faith and zeal" are essential to the Lasallian charism. The spirit of faith is nurtured through prayer and zeal is best served through the active participation in helping the poor ((Mark, 2011). In the book of Botana (2008) he presented a discussion on the understanding of the Lasallian Spirituality of Non- Christian educators. He posed the question - can a Lasallian spirituality serve a non-Christian person to express the "profound sense" of his life and his relationship with God? He answered this with this pronouncement:

Lasallian spirituality is for many non-Christian educators a means to be better believers in their own religion or humanistic beliefs. It is for all Lasallians a point of encounter and a source of common understandings for the 
mission that we share. We take a further step toward the roots: spirituality refers us to the charism that give it origin and, through it, to the Holy Spirit, who bestows it upon us. is is the root in which we need the definitive justification concerning why we are able to refer to the Lasallian spirituality of other believers who are nonChristians, or to the Lasallian charism that is embraced by non-Christian Lasallians. e Spirit of God, which "blows where it will" (John 3: 8), bestows its gifts not only to Christians but also to believers from other religions. (p.68)

This emphasis on Lasallian Spirituality of non- Christians presents the openness of the charism and its values to also be present even to teachers and students with other religion beside Catholic. It also affirms the value of communion in Mission highlighting the sharing of the Lasallian Mission regardless of religion or affiliation. On the other hand, Communion in Mission as a value that defines Lasallian Spirituality is defined in the Guiding Principles of Philippine Lasallian Family (2009)

As: Solidarity, co-responsibility and collaboration directed towards the fulfillment of a common mission. In a Christian perspective, communion in mission is rooted in communion with God, which leads to communion with others in the mission of building communion in the world. (Endnotes no. 14, p.18) Communion "recalls the dynamic of association" by which the first Brothers bonded together for the sake of the particular mission entrusted to them by God (Guiding Principles of the Philippine Lasallian Family, 2009, p. 8).

Botana (2008) shares that the link that unites communion with mission is the charism which in the end is the Spirit that lies in each of the persons who make up the Lasallian community. A Lasallian community is a group of persons that develops solidarity and unity of hearts.

\section{Synthesis}

The studies that were discussed in the review of related literature centered on Spirituality and leadership. Studies are also focused on the practice of spirituality in the academe and how teachers and educational leaders consider the impact of Spirituality in their leadership.

The review also provided a view on the difference of religion and spirituality and how this can be interrelated to one another. Religion can be a factor of spirituality however on the other hand spirituality may be independent from people's religious beliefs (Fry, 2003). Similar studies also were presented that provides a theory or knowledge that suggests that age, race and gender may be possible factors that affect spirituality of an individual.

Several studies also provided findings that spirituality in the academe are becoming to be an important aspect of the leadership of the teachers or educators. Decision-making is one aspect in leadership that can be influenced by the individual's spirituality. Further studies on leadership of teachers and the impact of spirituality creates a more meaningful and effective learning environment for both teachers and students.

There are not much studies on Lasallian spirituality of educators or of teacher leaders. Existing Lasallian research studies though provided additional view on Lasallian Spirituality and Charism and how this should be understood by members of the Lasallian family. It is in this light that this study hopes to provide more additional knowledge on how Lasallian Spirituality is lived and experienced by teachers specifically those who hold leadership positions. This study will hopefully provide more understanding and appreciation of how spirituality can be a facilitating factor to create a more effective learning and teaching experience for the Lasallian communities all over Asia. 


\section{Conceptual Framework}

Figure 1. Understanding Lasallian Spirituality of Teacher Leaders and its impact on creating an effective teaching and learning experience

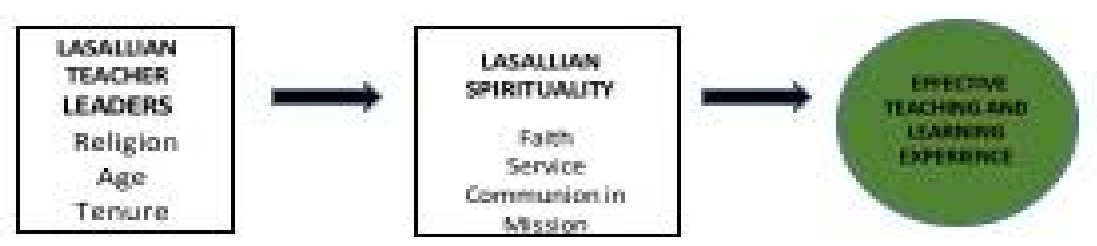

In understanding the Lasallian Spirituality of teacher leaders of Lasallian institutions the study would like to know the different aspects that defines the level of spirituality of teacher leaders. Teacher leaders are teachers that hold key responsibilities in schools like -mentoring, coaching, curriculum management, administration and management. Profile of teacher leaders like religion, age and tenure in the current institution will be considered as factors that might affect their level of spirituality. Given that they are teaching and leading in a Catholic institution and that the Lasallian Spirituality is based on Christian Spirituality (Botana, 2008), religion might be a factor on how Lasallian spirituality is developed.

Moreover, the qualitative research would like to further look for other aspects of the teacher leaders that can describe the Lasallian Spirituality of these Lasallian teacher leaders. Lasallian Spirituality will be presented as an expression of the Lasallian values of faith and zeal (Botana, 2008) and a commitment to be in solidarity or in communion with the other members of the community (Guiding Principles of the Philippine Lasallian Family, 2009).

Understanding the Lasallian spirituality of teacher leaders and describing how this affect their leadership, relationship and way of life will hopefully allow the study to further identify the impact on the teaching and learning experience of students and teachers in the community. The framework suggests that spirituality of teacher leaders provide a positive impact on how they lead in schools and how they effectively teach students.

\section{Research Questions}

The study provides a deeper understanding and description of Lasallian educators and leaders in Lasallian institutions in Asia. Acknowledging that these educational leaders come from varied backgrounds of culture and religion, it poses a greater need to define the characteristics of these individuals who shape the educational experience of Lasallian students based on the level of their Lasallian spirituality. The study aims to provide a description of how these leaders can are affected by their spirituality in the way they lead and teach. Specifically this study aims to answer the following questions:

1. What is the level of Lasallian Spirituality of the teacher leaders? Is religion, age and years in the service of teaching factors that affect their level of Spirituality? If these are significant factors, in what way do they affect their spirituality?

2. Are Christian and Non-Christian teacher leaders different in the way they practice their leadership and sprituality? In what way are they different?

3. In what way are students affected or impacted by these Lasallian teacher leaders with varied faith and religious backgrounds? How do their spirituality affect the way they lead other teachers and teach students? 
The answers will provide a characterization of Lasallian educational leaders and how they can create an effective teaching and learning experience in Lasallian institutions. This study will provide information and knowledge on how teacher leaders can be formed and developed imbibing the Lasallian values of faith, service and communion in Mission.

\section{Research Design}

The study aims to provide a thorough description of the Lasallian Spirituality of teacher leaders of Lasallian institutions. The study would like to look into the lived experiences, thoughts and characteristics of these educational leaders to determine how spirituality is expressed and manifested in their life as a teacher and as a leader. It is for this reason why this study is qualitative research which will utilize a mixed method approach. The mixed method approach will be utilized to provide various ways to gather data from the participants of the study. A mix of quantitative and qualitative research designs will be utilized to gather and analyze data. Specifically, this study aims to conduct an explanatory sequential research design as it will gather quantitative data and after which a qualitative case study will be done on identified cases from the results of the initial analysis. Quantitative data will be identified from the Level of Spirituality of sixty seven (67) teacher leaders with different faith backgrounds from the Lasallian schools from the Asia-Pacific Region. These data will provide descriptive statistics and correlation on age, religion and tenure. A Lasallian Spirituality Scale will be used to measure the Level of Spirituality and the correlation to the factors that might affect the spirituality of teacher leaders. After analyzing the quantitative data, identified cases will be drawn from the sample and will be invited for in-depth interviews. The interviews will draw answers on how their spirituality is affecting their life and work as a Lasallian educator and leader. Drawing stories from their experiences in teaching and leading will be the focus of the interviews. A triangulation method will also be utilized to also gather data from students and teachers focusing on their feedback on the participant's way of teaching and leading. Interviews will be subject to qualitative data analysis. The mixed method design will be utilized as the approach to further describe how spirituality can affect the teaching and leadership experiences of Lasallian educational leaders. Employing both the quantitative and qualitative methods of research will provide a more comprehensive description of how teacher leaders create a more effective teaching and learning experience because of their spirituality and leadership.

\section{Participants}

The study will use a purposive sampling method in identifying Lasallian teacher leaders in institutions in the Asia and the Pacific. The Lasallian Spirituality Scale will be conducted to sixty- seven (67) teacher leaders from the member countries from the Lasallian East Asia District - Philippines, Singapore, Hongkong, Japan, Malaysia and India. The study purposively will choose thirty (30) Christians and thirty (30) Non- Christian teacher leaders. Teacher leaders are those who held or are currently holding leadership responsibilities including but not limited to coaching, mentoring, curriculum management, administration work and management in schools. Further, specific participants will be identified as part of the qualitative case study. These participants are those which are outliers or will have extreme answers based from the quantitative analysis. Identified participants will be subjected to in depth interviews. There will also be around 3-5 students and 3-5 teachers who are colleagues of these identified participants that will be invited for interview.

\section{Data Collection}

The research will have a mixed method design which will use various instruments as a tool to gather data. In the quantitative research method, the study will use the Lasallian Spirituality Assessment Scale developed and validated by Estanislao (2015). The Scale is a 15-item scale with three (3) factors that represent, Faith, Service and Communion in Mission. This instrument will be distributed to sixty (60) teacher leaders with varied faith 
backgrounds - 30 are non-Christians and 30 Christians. These teacher leaders will be from the different Lasallian institutions from the East Asia. The instrument will be distributed through an online form and respondents will be notified through email. The respondents will be instructed to indicate their degree of agreement or disagreement for each of the statements by encircling the number closest to their response using a scale from "5" as Strongly Agree to "1" as Strongly Disagree with "3" as Undecided (Estanislao, 2015).

In the qualitative research method, interviews will be conducted to ten (10) select cases from the sample of participants. An interview guide will be utilized drawing stories and experiences describing the spirituality and leadership of these identified participants. To achieve triangulation, data from interviews of students and teacher subordinates will also be collected and will be analyzed. To summarize, data will be collected from 60 respondents of the Lasallian Spirituality Scale, interview responses from the ten (10) cases identified and lastly interview responses from 3-5 students and teacher subordinates.

\section{Data Analysis}

Data will be drawn and analyzed from the 60 respondents of the Lasallian Spirituality Assessment Scale using descriptive statistics, correlation and regression analysis. Descriptive statistics will provide information on the number of Christians and Non-Christian respondents, their age, gender and religion. Scores that measures their level of spirituality will be computed using a scoring guide. The mean scores will be part of the descriptive statistics and will be further analyzed. Factors on age, religion and tenure will be correlated to the scores on Lasallian spirituality to identify relationship and its significance. A regression analysis can also be employed especially on the factor of religion and spirituality. A test of significance will be employed on the relationship of these factors to identify significant factors that might affect the spirituality of the teacher leaders. To identify specific cases to be subjected for interviews, an outliers test can be done on the statistical data. Other cases can also be identified through the use of scatter plots and outliers test. The respondents from the sample will be identified for further data collection. Data from interviews with these chosen respondents will be content analyzed. Certain themes will be coded and further analyzed to provide an overall description of the characteristics of these teacher leaders on spirituality and leadership.

\section{Initial Results of the Study}

This study made use of descriptive statistics and correlation tests to analyze the relationship of age, gender and years of service or tenure of teachers in La Salle schools to their levels of Lasallian spirituality. A total of 67 respondents coming from different La Salle schools in Asia answered the survey on assessing their level of Lasallian Spirituality through Google forms. The average age of the respondents is 44.8 and are mostly males. The average years of service of these teachers in La Salle schools is 14 years. Majority of the respondents are Christians (61\%) from the Roman Catholic denomination. The following tables summarize the frequencies of age, gender, religion and years of service of teacher respondents.

To test the assumption that the age, religion and tenure or service in working in a La Salle school has a significant relationship or effect on their levels of Lasallian spirituality, this study made use of six (6) variables - one outcome variable which is Lasallian Spirituality and five (5) predictor variables - age, religion, tenure in La Salle school, years working in the academe and gender. Gender was also included to provide additional confirmation to previous studies made on spirituality of educators however Gender is not the variable that is included in the model that this study is trying to prove. The same with gender, the years of service in the academe is not a main independent variable that the model of this study is proving but the a description and analysis was made to further support previous research. 
The Shapiro-Wilk normality tests revealed that the following variables' distribution were, strictly speaking, not normal: Lasallian Spirituality $(\mathrm{W}=.946, \mathrm{p}=.006)$, age $(\mathrm{W}=.978, \mathrm{p}=.006)$, years in current La Salle school $(\mathrm{W}=.931, \mathrm{p}=.001)$. However, the distribution of years working in academe $(\mathrm{W}=.971, \mathrm{p}=.134)$ appeared normal.

Thus the study made use of the Spearman's Rank Rho correlation test to determine the relationship of the nonnormal distribution of the continuous variables - age, years of service in a La Salle school. Pearson's correlation test was used on the other hand to test the relationship of Lasallian Spirituality with the years working in academe or school. All variables positively are correlated with Lasallian Spirituality but the relationships are not significant.

The Welch Two Sample t-test of significance was used on the two variables gender and religion. Results showed that there is a statistically significant mean difference in the level of Lasallian Spirituality between Christians ( $\mathrm{M}=4.46, \mathrm{SD}=.42)$, and Non-Christians $(\mathrm{M}=4.20, \mathrm{SD}=.40), \mathrm{t}(55)=2.54, \mathrm{p}=.013$. Christians have higher levels of Lasallian Spirituality compared to Non-Christian respondents. However, test results showed that there is no significant mean difference on the level of Lasallian spirituality between males $(\mathrm{M}=4.36, \mathrm{SD}=.42)$ and female respondents $(\mathrm{M}=4.37, \mathrm{SD}=.30), \mathrm{t}(64)=.07, \mathrm{p}=.936$. Tables 7 and 8 show the results below.

To further identify the effect of the relationship of the variables identified in the study - Age, tenure and religion with Lasallian Spirituality, a linear regression analysis was done on these variables. As expected religion has a significant predictor of the level of Lasallian spirituality showing that the test was significant. Further it showed that the various linear regression models on the variables used as a predictor of Lasallian Spirituality.

The results of the statistical analysis done on the study showed that age and tenure is not a factor in determining the levels of Lasallian spirituality of teachers. On the other hand, religion has an effect on the levels of Lasallian Spirituality of teachers.

This initial result of the study provided the researcher the data needed to proceed with the further qualitative research. Certain participants will be interviewed to further validate the results and to provide answers to the other research questions.

\section{References}

A.W. Chickering, Education and Identity (San Francisco, CA: Jossey- Bass, 1969). P.T. Terenzini, C. Theophilides, and W.G. Lorang, "Influences on Students' Perceptions of their Academic Skill Development During Col- lege,” The Journal of Higher Education 55(4) (1984):621-636.

Bago, A. L. (2008). Curriculum Development: The Philippine experience. Quezon City: C\&E Pub., 2008. Bolman, L. G., and Deal, T. E. LEADING WITH SOUL. San Francisco: Jossey-Bass, 1995.

Botana, A. (2008). Thematic Vocabulary of Lasallian Association. Lasallian Essays.

Dalia, D. V. (2005). School Leadership and Spirituality. Ontario Institute for Studies in Education. https://doi.org/10.1016/B978-012397720-5.50034-7

de Kierk-Luttig, J. (2008). Spirituality in the workplace: a reality for South African teachers? South African Journal of Education, 28(4), $\quad$ 505-517. http://ezproxy.umsl.edu/login?url=http://search.ebscohost.com/login.aspx?direct=true \&db=afh\&AN=35875785 $\&$ site $=$ ehost-live $\&$ scope $=$ site 
Estanislao, S. (2015). VALIDATION OF THE LASALLIAN SPIRITUALITY ASSESSMENT SCALE. The Guidance Journal, XLII(2), 1-20.

Fry, L. W. (2003). Toward a theory of spiritual leadership. Leadership Quarterly, 14(6), 693-727. https://doi.org/10.1016/j.leaqua.2003.09.001

Gilligan,P. \& Furness, S. (2006) ; The Role of Religion and Spirituality in Social Work Practice: Views and Experiences of Social Workers and Students, The British Journal of Social Work, Volume 36, Issue 4, Pages $617-637$, https://doi.org/10.1093/bjsw/bch252

Harrison, C., \& Killion, J. (2008). Ten Roles for Teacher Leaders. Educational Leadership,65(1), 1-5. Retrieved from http://www.csun.edu/ krowlands/Content/SED610/Leadership/harrison and \%5Cnkillion ten roles for teacher leaders.pdf

Hooper Atlas, B. L. (2002). The role of spirituality in the work of african -american women principals in urban schools (Order No. 3049447). Available from ProQuest Dissertations \& Theses A\&I. (305474045). Retrieved from https://search.proquest.com/docview/305474045?accountid=190474

Jones, A. (2010). Leadership and Spirituality: The invisible leadership of African American school administrators as pastors.

Klerk-Luttig, J. D. (2008). Spirituality in the workplace: a reality for South African teachers?. South African Journal of Education, 28(4), 505-517.

Laurence, P. (1999). Can religion and spirituality find a place in higher education. About Campus, 4(5), 11-16.

Lindholm, J. a. (2007). Spirituality in the academy: Reintegrating our lives and the lives of our students. About Campus, 12(4), 10-17. https://doi.org/10.1002/abc.218

Lindholm, J. A., \& Astin, H. S. (2006). Understanding the "interior" life of faculty: How mportant is spirituality? Religion and Education, 33(2), 64-90.https://doi.org/10.1080/15507394.2006.10012377

Mark, J. (2011). Extending Lasallian Charism : Its Texts And Lived Contexts for the Spirituality Of Teachers, (3), 75-77.

Massenburg, M. J. (2010). The Perceptions of Public School Leaders About the Role of Spirituality Plays in Decision-Making. Saint Louis University.

Guiding Principles of the Philippine Lasallian Family (2009) La Salle Provincialate, Metro Manila.

Saroglou, V., \& Muñoz-garcía, A. (2008). Individual differences in religion and spirituality: An issue of personality traits and/or values. Journal for the Scientific Study of Religion, 47, 83-101. https://doi.org/10.1111/j.1468-5906.2008.00393.x

Tisdell, E. (2001). ED459370 2001-00-00 Spirituality in Adult and Higher Education . ERIC Digest . Spirituality in Adult and Higher Education . ERIC Digest on Adult Career and Vocational Education, 1-8.

Zinnbauer, B. J., K. I. Pargament, and A. B. Scott. 1999. The emerging meanings of religiousness and spirituality: Problems and prospects. Journal of Personality 67:889-919. 